\title{
ANALISIS BIAYA, PENDAPATAN DAN R/C PADA AGROINDUSTRI SALE PISANG AMBON (Studi Kasus pada Perusahaan Sale Pisang Ambon di Desa Pakemitan I Kecamatan Cikatomas Kabupaten Tasikmalaya)
}

\author{
YESI SUSANTI $^{1}$, DINI ROCHDIANI ${ }^{2}$, AGUS YUNIAWAN ISYANTO ${ }^{1}$ \\ ${ }^{1}$ Fakultas Pertanian Universitas Galuh \\ ${ }^{2}$ Fakultas Pertanian Universitas Padjadjaran \\ *Email: yessisusanti.14@gmail.com
}

\begin{abstract}
ABSTRAK
Penelitian ini bertujuan untuk mengetahui: (1) Besarnya biaya yang dikeluarkan pada agroindustri sale pisang Ambon pada satu kali proses produksi, 2) Besarnya penerimaan dan pendapatan pada agroindustri sale pisang Ambon pada satu kali proses produksi, dan 3) Besarnya R/C pada agroindustri sale pisang Ambon pada satu kali proses produksi. Penelitian ini dilaksanakan di Desa Pakemitan 1 Kecamatan Cikatomas Kabupaten Tasikmalaya dengan menggunakan studi kasus. Perajin sale pisang Ambon di Desa Pakemitan 1 Kecamatan Cikatomas Kabupaten Tasikmalaya sebanyak 2 orang dan semuanya diambil sebagai responden (sensus). Data yang diperoleh dianalisis secara deskriftip kuantitatif. Hasil penelitian menunjukkan: (1) Biaya yang dikeluarkan sebesar Rp 1.291.197,20 dalam satu kali proses produksi, (2) Penerimaan Rp 3.600.000 dan pendapatan Rp 2.308.803 dalam satu kali proses produksi, dan (3) R/C sebesar 2,79 yang menunjukkan bahwa dari setiap Rp 1,00 biaya yang dikeluarkan akan diperoleh penerimaan $\mathrm{Rp} 2,79$ dan pendapatan $\mathrm{Rp} 1,29$.
\end{abstract}

Kata kunci: Analisis biaya, Agroindustri, Sale pisang

\section{PENDAHULUAN}

Agroindustri adalah pendekatan untuk pengembangan pertanian pada masa yang akan datang karena industri pengolahan hasil pertanian (agroindustri) ditangani secara utuh, mulai dari proses produksi, mengolah hasil, pemasaran dan aktivitas lain yang berkaitan dengan kegiatan pertanian (agribisnis). Agroindustri bukan saja mampu sebagai sumber pertumbuhan baru bagi sektor pertanian, tetapi juga mampu menyerap banyak tenaga kerja. Agroindustri juga merupakan suatu sistem pengolahan secara terpadu antara sektor pertanian dengan sektor industri sehingga akan diperoleh nilai tambah dari hasil pertanian tersebut (Soekartawi, 2006).

Pisang merupakan salah satu komoditas pertanian yang mudah rusak, sehingga perlu adanya suatu penanganan pasca panen yang mampu memberikan nilai tambah baik harga ataupun kualitas yang lebih baik daripada komoditas mentahnya. Salah satu pengolahan pisang yaitu sale pisang.

Sale pisang adalah makanan hasil olahan dari buah pisang yang diiris tipis kemudian dijemur. Sale pisang ini bisa langsung dimakan atau digoreng dengan tepung terlebih dahulu. Selain itu, saat ini 
sale pisang sudah menembus pasar internasional (Bambang, 2009).

Kecamatan Cikatomas merupakan salah satu wilayah yang menghasilkan berbagai macam produk olahan pisang, salah satunya adalah sale pisang goreng. Sale pisang goreng merupakan produk industri rumahan yang diusahakan oleh masyarakat di Kecamatan Cikatomas.

\section{METODE PENELITIAN}

Jenis penelitian ini yang digunakan adalah studi kasus dengan mengambil kasus pada perusahaan sale pisang Ambon yang ada di Desa Pakemitan 1 Kecamatan Cikatomas Kabupaten Tasikmalaya. Menurut Nazir (2009), studi kasus adalah penelitian tentang satu subjek penelitian yang berkenaan dengan suatu fase spesifik atau khas dari keseluruhan personalitas.

Data yang digunakan dalama penelitian ini terdiri atas data primer dan sekunder. Data primer adalah data yang diperoleh secara langsung dari perajin sale pisang Ambon yang dijadikan sebagai responden, sedangkan data sekunder adalah data yang diperoleh dari literaturliteratur dan data dari instansi atau dinas terkait dengan penelitian ini.

Perusahaan sale pisang Ibu Mumun dipilih secara sengaja (purposive sampling) sebagai sampel dengan pertimbangan menghasilkan produksi tertinggi di Desa Pakemitan 1, dan merupakan satu-satunya perusahaan yang mempunyai ijin usaha dengan P-IRT No. 2143202059019. Menurut Sugiyono (2010), purposive sampling adalah teknik untuk menentukan sampel penelitian dengan beberapa pertimbangan tertentu yang bertujuan agar data yang diperoleh nantinya bisa lebih representatif.

Analisis biaya dilaksanakan dengan menggunakan persamaan berikut (Suratiyah, 2006):

\section{$\mathrm{TC}=\mathrm{TFC}+\mathrm{TVC}$}

Keterangan:

$\mathrm{TC}=$ Total Cost (biaya total)

TFC = Total Fixed Cost (biaya tetap total) TVC =Total Variable Cost (biaya variabel total)

Penerimaan total (Total Revenue) merupakan perkalian jumlah produksi dengan harga jual satuan produksi, dan dihitung dengan rumus sebagai berikut (Suratiyah, 2006):

$$
\mathbf{T R}=\mathbf{Y} \text {. Hy }
$$

Keterangan:

TR = Total Revenue (Penerimaan Total)

$\mathrm{Y}=$ Jumlah produk yang dihasilkan $(\mathrm{kg})$

$\mathrm{Hy}=$ Harga jual produksi $(\mathrm{Rp} / \mathrm{kg})$

Pendapatan adalah penerimaan total (Total Revenue) dikurangi dengan biaya total (Total Cost), dan dihitung 
denganmenggunakan rumus sebagai berikut (Suratiyah, 2006):

$\mathbf{P d}=\mathbf{T R}-\mathbf{T C}$

Keterangan:

Pd = Pendapatan

$\mathrm{TR}=$ Total Revenue $($ Penerimaan total $)$

$\mathrm{TC}=$ Total Cost (Biaya total $)$

Menurut Rodjak (2006), R/C adalah perbandingan antara penerimaan dengan biaya, dan dihitung dengan persamaan berikut:

\section{$\mathrm{R} / \mathrm{C}=\mathrm{TR} / \mathrm{TC}$}

Keterangan:

$\mathrm{TR}=$ Total Revenue $($ Penerimaan Total $)$

$\mathrm{TC}=$ Total Cost (Biaya Total)

Kelayakan usaha berdasarkan metode $\mathrm{R} / \mathrm{C}$ menggunakan kriteria sebagai berikut:

a. $\mathrm{R} / \mathrm{C}>1$, maka usaha tersebut untung sehingga layak diusahakan.

b. $\mathrm{R} / \mathrm{C}=1$, maka usaha tersebut tidak untung tidak rugi (impas).

c. $\mathrm{R} / \mathrm{C}<1$, maka usaha tersebut rugi dan tidak layak diusahakan.

\section{HASIL DAN PEMBAHASAN}

\section{Identitas Responden}

Identitas responden yang dibahas dalam penelitian ini meliputi umur, pendidikan, pengalaman berusaha, dan jumlah tanggungan keluarga.
Umur merupakan salah satu faktor yang dapat mempengaruhi seseorang dalam bekerja dimana semakin tua umur seseorang maka kemampuan fisik dalam bekerja semakin berkurang. Ibu Mumun dan Ibu Yati yang dijadikan sebagai responden berumur 51 tahun dan 40 tahun, sehingga termasuk dalam usia produktif (15-64 tahun).

Tingkat pendidikan perannya cukup besar terhadap seseorang dalam kegiatan suatu usaha, karena tingkat pendidikan dapat mempengaruhi seseorang dalam menerima dan melaksanakan hal-hal yang baru. Pendidikan responden adalah tamatan Sekolah Dasar (SD) dan Sekolah Menengah Pertama (SMP), sehingga bisa dikatakan kalau pendidikan responden tergolong rendah.

Tanggungan keluarga merupakan salah satu faktor yang sangat erat kaitannya dengan kemampuan responden dalam mengelola usahanya. Semakin banyak jumlah tanggungan keluarga, maka responden akan semakin termotivasi dalam melaksanakan usahanya dengan harapan pendapatan yang diperolehnya dapat mencukupi kebutuhan hidup keluarganya.

Tanggungan keluarga yang dimaksud dalam penelitian ini adalah jumlah anggota keluarga responden yang masih menjadi tanggung jawab responden dalam 
memenuhi kebutuhan hidupnya. Berdasarkan hasil penelitian diketahui bahwa jumlah tanggungan keluarga responden 1 adalah 3 orang, sedangkan tanggungan keluarga responden 2 adalah 2 orang.

Pengalaman berusaha merupakan salah satu faktor yang menentukan keberhasilan dalam usaha agroindustri sale pisang Ambon. Semakin lama pengalaman berusaha, maka akan semakin tinggi keterampilan yang dimilikinya dalam melakukan proses produksi, yaitu dengan mempelajari pengalaman yang dialami sehingga akan lebih mampu dalam menghadapi kesulitan dan cara penanggulangannya. Pengalaman Ibu Mumun dalam berusaha agroindustri sale pisang Ambon sudah cukup lama, yaitu sekitar 15 tahun, sedangkan Ibu Yati sekitar 5 tahun, Hal ini menunjukkan bahwa kedua responden sudah cukup berpengalaman dalam menjalankan usahanya.

\section{Pengadaan Sarana Produksi}

Penyediaan sarana produksi dilaksanakan sendiri oleh responden. Bahan baku utamanya yang digunakan adalah pisang Ambon yang dibeli dari tengkulak atau pemasok, begitu pula untuk bahan-bahan produksi, seperti kayu bakar yang didapat dari pemasok.

\section{Proses Produksi Sale Pisang Ambon}

Proses produksi sale pisang Ambon di perusahaan sale Ambon ini ada beberapa tahapan, yaitu:

1) Pengupasan dan Pengirisan

Pisang dikupas kemudian diiris tipis menggunakan pisau (sesuai dengan permintaan) secara memanjang. Hasil irisan langsung ditampung dalam tampan/ebeg guna mempermudah dalam proses penyusunan untuk penjemuran.

2) Penjemuran

Pisang yang sudah diiris selanjutnya disusun dengan rapih pada alat penjemur (ebeg), kemudian dijemur selama 1-3 hari (tergantung pada teriknya sinar matahari) sampai irisan pisang tersebut kering (sudah menjadi sale pisang mentah).

3) Penggorengan

Irisan buah pisang yang sudah kering (sale pisang mentah) dimasukan pada adonan tepung terlebih dahulu kemudian digoreng menggunakan minyak goreng yang cukup banyak hingga semua bahan terendam. Selama penggorengan dilakukan pengadukan secara perlahan-lahan. Penggorengan 
dilakukan sampai sale pisang cukup kering serta berwarna kuning kecoklatan.

4) Penirisan Minyak

Hasil penggorengan selanjutnya ditiriskan dengan menggunakan peniris/saringan minyak hingga minyak yang ada menetes tuntas.

5) Sortasi

Proses sortasi dilakukan untuk mengklasifikasi kualitas atau mutu dengan cara memilah dan mengolompokkan sale pisang berdasarkan ukuran, warna, dan bentuknya dilakukan secara manual.

6) Pengemasan dan Pelabelan

a. Pengemasan

Pengemasan fungsinya untuk meningkatkan daya simpan produk. Bahan pengemasan yang digunakan untuk sale pisang adalah plastik kemasan.

b. Pelabelan

Pelabelan bertujuan untuk memberi informasi tentang produk dan memberi penampilan yang menarik. Informasi trsebut terdiri atas nama produk, nama perusahaan, dan alamat perusahaan.

\section{Analisis Biaya, Penerimaan, Pendapatan} dan $R / C$

Analisis biaya, penerimaan, pendapatan dan $\mathrm{R} / \mathrm{C}$ pada agroindustri sale pisang dapat dilihat pada Tabel 1.

Tabel 1. Analisis Finansial Agroindustri Sale Pisang

\begin{tabular}{|c|c|c|}
\hline No & Uraian & Jumlah \\
\hline \multirow[t]{5}{*}{1} & Biaya Tetap & \\
\hline & $\begin{array}{l}\text { 1. Pajak Bumi dan } \\
\text { Bangunan }\end{array}$ & 48,61 \\
\hline & 2. Penyusutan Alat & $9.543,77$ \\
\hline & 3. Bunga Modal & 1,82 \\
\hline & Biaya Tetap Total (Rp) & $9.594,20$ \\
\hline \multirow[t]{17}{*}{2} & Biaya Variabel & \\
\hline & Sarana Produksi & \\
\hline & a. Kayu Bakar & $52.500,00$ \\
\hline & b. Pisang Ambon & $670.000,00$ \\
\hline & c. Minyak Goreng & $139.000,00$ \\
\hline & d. Plastik & $35.000,00$ \\
\hline & e. Tepung Terigu & $112.000,00$ \\
\hline & f. Tepung Tapioka & $41.000,00$ \\
\hline & g. Gula Pasir & $23.000,00$ \\
\hline & h. Mentega & $10.750,00$ \\
\hline & i. Karbit & 500,00 \\
\hline & j. Stepler & $52.500,00$ \\
\hline & k. Label & 250,00 \\
\hline & 1. Isi Stepler & $1.750,00$ \\
\hline & Tenaga kerja (Rp) & $240.000,00$ \\
\hline & Bunga modal (Rp) & 245,28 \\
\hline & $\begin{array}{l}\text { Biaya Variabel Total } \\
\text { (Rp) }\end{array}$ & $1.291 .197,20$ \\
\hline 3 & Biaya Total (Rp) & $1.291 .197,20$ \\
\hline \multirow[t]{4}{*}{4} & Penerimaan & \\
\hline & Produksi (kg) & 90 \\
\hline & Harga jual (Rp/kg) & 40.000 \\
\hline & Penerimaan total $(\mathrm{Rp})$ & 3.600 .000 \\
\hline 5 & Pendapatan (Rp) & 2.308 .803 \\
\hline 6 & $\mathrm{R} / \mathrm{C}$ & 2,79 \\
\hline
\end{tabular}

Analisis finansial pada agroindustri sale pisang Ambon dalam satu kali proses produksi menunjukkan besarnya biaya total $\mathrm{Rp} 1.291 .197,20$, penerimaan $\mathrm{Rp}$ 
3.600.000, pendapatan Rp 2.308.803, dan $\mathrm{R} / \mathrm{C}$ sebesar 2,79.

$\mathrm{R} / \mathrm{C}$ sebesar 2,79 menunjukkan bahwa dari setiap $\mathrm{Rp} 1$ biaya yang dikeluarkan, perajin akan memperoleh penerimaan $\mathrm{Rp} 2,79$, dan pendapatan $\mathrm{Rp}$ 1,79 .

\section{KESIMPULAN DAN SARAN}

\section{Kesimpulan}

Berdasarkan hasil penelitian dan pembahasan maka dapat diambil kesimpulan sebagai berikut:

1. Biaya produksi yang dikeluarkan oleh agroindustri sale pisang Ambon sebesar Rp 1.291.197,20.

2. Penerimaan yang diperoleh perajin agroindustri sale pisang Ambon sebesar Rp 3.600.000.

3. Rata-rata pendapatan yang diperoleh perajin agroindustri sale pisang Ambon adalah Rp 2.308.803.
4. R/C sebesar 2,79 menunjukkan bahwa agroindustri sale pisang Ambon layak untuk diusahakan.

\section{Saran}

Berdasarkan kesimpulan penelitian, maka diajukan saran, yaitu:

1. Perusahaan hendaknya tetap melakukan produksi sale pisang Ambon karena usaha tersebut memberikan keuntungan bagi perusahaan.

2. Perlu peningkatan skala produksi sehingga akan terjadi peningkatan pendapatan bagi pengelola perusahaan.

\section{DAFTAR PUSTAKA}

Bambang, C. 2009. Usahatani Pisang dan Penanganan Pascapanen. Yogyakarta.

Nazir M, 2009. Metode Penelitian. Bogor: Ghalia Indonesia.

Rodjak, A. 2006. Manajemen Usahatani. Bandung: Pustaka Giratuna.

Soekartawi. 2006. Pengantar Agroindustri. Jakarta: Raja Grefindo Persada.

Sugiyono. 2007. Metode Penelitian Bisnis. Bandung: Alfabeta.

Suratiyah, K. 2006. Ilmu Usahatani. Jakarta: Penebar Swadaya. 